\title{
CAUSAL FACTORS OF DISHARMONY ISSUES ON LICENSING COASTAL RECLAMATION IN SAMPANG AND BANGKALAN REGENCIES ${ }^{\Omega}$
}

\author{
Rina Yulianti and Mufarrijul Ikhwan \\ Fakultas Hukum Universitas Trunojoyo, Indonesia \\ E-mail: rina.yulianti@trunojoyo.ac.id
}

\begin{abstract}
This research is to investigate the contributing factors on the disharmony of licensing coastal reclamation in Sampang and Bangkalan Regencies. Socio legal research approach was used through in-depth interviews and observations. The study was conducted in areas with reclamation activities and subsequently considering the relevant documents to analyze as the secondary data. The findings of this research demonstrate factors leading to disharmony of licensing coastal reclamation: the regional government of Sampang and Bangkalan regencies has not synchronized the reclamation policies with the presidential regulation. Reclamation in Sampang and Bangkalan are not based on the Presidential Regulations Number 122 Year 2012 on the Licensing Coastal Reclamation. The license of reclamation in Sampang should have been issued by district or provincial government instead of by the head of village. Reclamation license in Bangkalan should have been issued by the Ministry of Maritime Affairs and Fisheries because it is located in the National Strategic Areas. The fact, it was granted by the local government. Harmonization consequently becomes an important part to construct an integrative law for realizing central and local authority's conformity in introducing the policy to control of coastal spatial utilization.
\end{abstract}

Keywords: coastal, disharmony, licensing, reclamation

\begin{abstract}
Abstrak
Penelitian ini bertujuan untuk mengetahui faktor-faktor yang menyebabkan disharmoni dalam pemberian izin reklamasi di Kabupaten Sampang dan Bangkalan. Untuk mencapai tujuan penelitian ini digunakan metode penelitian socio legal research, interview mendalam dan observasi dilakukan di daerah yang ada kegiatan reklamasi kemudian dilengkapi dengan data sekunder berupa studi dokumen. Hasil penelitian menemukan faktor yang menyebabkan disharmoni dalam pemberian izin reklamasi antara lain, Pemerintah Daerah Sampang dan Bangkalan belum menyelaraskan kebijakan reklamasi dengan peraturan diatasnya. Perizinan pelaksanaan reklamasi pantai, yaitu di Kabupaten Sampang dan Kabupaten Bangkalan tidak mengacu pada Peraturan Presiden Nomor 122 Tahun 2012 tentang Perizinan Reklamasi Pantai. Izin reklamasi pantai di Kabupaten Sampang seharusnya dikeluarkan oleh pemerintah daerah kabupaten/provinsi faktanya hanya berdasarkan izin dari kepala desa. Izin reklamasi pantai di Kabupaten Bangkalan seharusnya dikeluarkan oleh Kementerian Kelautan dan Perikanan karena berada pada Kawasan Strategis Nasional, faktanya izin diberikan oleh pemerintah kabupaten setempat. Harmonisasi menjadi bagian penting untuk mengkonstruksi hukum yang integratif agar bisa mewujudkan keseragaman pola kewenangan pusat dan daerah dalam mengeluarkan kebijakan pengendalian pemanfaatan ruang pesisir.
\end{abstract}

Kata kunci: disharmoni, perizinan, pesisir, reklamasi

Introduction:

The main purpose of the coastal reclamation is to provide widely extended land territories for any legal purposes which have been

$\Omega$ Integrated Coastal Management as The Base of Reclamation Harmonization Regulation, Applied Product Research, 2017, Number of Contract 2986/UN46.3.1/PN/ 2017 practiced worldwide. The small space for human activities includes human residence, industrial expansion, and trade lead to its practice.

The scope of the Law Number 27 Year 2007 on the Coastal Area Management and Small Islands particularly regulates the meeting point between waters and land; to the part of the 
land areas cover administrative zones and 12 miles to waters measured from coastline and or to archipelagic waters. The major scope of the Law encompasses three points: planning, management, and supervision and control.

This research is the continuation of previous research on coastal reclamation in southern coastal area of Madura revealing that there is no coherence between governmental technical institutions in making policy of reclamation implementation resulting in new problem on the certainty of object, subject, and right status and reclamation activity. Furthermore, the Local Government authority in coastal area is unclear as governed in Local Government Law that the regency government's authority is included into the provincial government's authority. Many central and local regulations have not been integrated in governing the object of coastal reclamation; there are regulations of Rencana Tata Ruang Wilayah/RTRW (Region Layout Plan) from central to local level, Regulations of Public Work Minister, Home Affairs Minister and Communication Minister. Therefore, a harmonization is required in governing the management of coastal reclamation particularly in controlling licensing over the coastal reclamation object, to make the coastal area development integrated based on an integrated coastal management.

The Law Number 27 Year 2007 Article 3 governs that one of the principles of Coastal Area management and Small Islands is integrated. In practice, administering the object/activities of the reclamation frequently raises conflict among authorities even though the Presidential Regulation Number 122 Year 2012 on the reclamation in coastal areas and small is-lands has regulated the authorities to issue the permission. In fact, it is overlapping. There is a number of regulations underlying the management of reclamation including Presidential Decree, the regulation of Public Work Ministry, the regulation of Transportation Ministry and of Provincial or regional regulation. The given regulations are potentially conflicting in licensing the coastal reclamation particularly when the same regulations are under two different authorities, central and district. To achieve the
Integrated Coastal Management (ICM), authority distribution should then consider the integration of centralization and decentralization without polarizing the views.

Most reclamation land around southern coastal area of Kamal, Labang, Kwanyar and Modung Sub districts are made to expand their preexisting land, even to heap new land for certain purpose. The result of our investigation shows that the reclamation land functions as residence, business area, and education foundation. People state that they master the land hereditarily with grant or inheritance; some others are obtained through trading and they say that their mastery is legitimate because they have paid land and building tax through the Village Head. ${ }^{1}$

The problem of land reclamation along southern coastal in Camplong and Sreseh Sub Districts attracts much attention, particularly in Camplong Sub District, the strategic location of which resulting in new lands obtained by means of filling in the coastal with soil. Sampang Regency, related to the people's preference to the mastery of reclaimed land, has different backgrounds of acquisition. The Village Head of Labuhan Village, Sreseh Sub District said that all of lands resulting from reclamation along coastal area have tax payment evidence. However, almost all of lands have no certificate. The citizens interviewed say that they do not know the status of land they master, and even many of them answer that they got it from inheritance and purchasing, all of which are through Village Head. $^{2}$

The problem of coastal reclamation also occurs in Makasar which the policy over utilizing land activity resulting from reclamation of Losari Coast has not been coordinated coherently between municipal and provincial governments. It is because Local Government authority in coastal area is unclear as governed in Local Government Law that municipal government's au-

\footnotetext{
Rina Yulianti, Et. Al. "Urgensi Pengaturan Reklamasi Pantai di Wilayah Pesisir Selatan Madura", Yustisia, 91 Edition Vol. 4 No. 1, January-April 2015, p. 67.

2 Ibid, p. 68.
} 
thority is included into Provincial Government's authority. ${ }^{3}$

The distinctive rules to the same case are potentially legally conflicting. The regulation in each institution is frequently inappropriate, incompatible, and overlapping. Therefore, ICM is required. ICM is idealized as a resource management system which employs an integrative, holistic approach and as interactive planning process in addressing the compex management issues in the coastal areas (Chua Tia-Eng and JR Clarks, 1995). Guiding principles of UNCED 1992, especially Agenda 21 Chapter 17, Rio Declaration 1992, and Johannesburg Declaration 2002 base the concept of ICM. The integrated management is characterized by the presence of coordination in duty, authority, and responsibility between governmental institutions both horizontal and vertical integration. The ICM approach is used to manage the coastal areas and consists of law components. The coastal area management in each country resolute and harmonize among the law of National (based on the structure of hierarchical law applied) and the International Law (such as convention, international treaty, and protocol) that have been ratified in the form of Law or included in the national law system. ${ }^{4}$

The disintegrated reclamation management leads to disharmony to its organization because of the presence of overlapping authorities to the same object. The current study acts as the basis of ICM. Therefore, the paper aims to investigate: "What Factors do cause the disharmony of coastal reclamation regulation in Sampang and Bangkalan Regencies?"

\section{Research Methods}

This is non-doctrinal (socio-legal research) approach studying the empirical legal phenomena to reveal the theoretical under-

\footnotetext{
Suhayati, et.al., "Aspek Hukum Kebijakan Pemanfatan Tanah Hasil Reklamasi Pantai Losari di Kota Makassar", Jurnal Pasca FH Universitas Hasanuddin Makasar, 2013, p. 11. Retrivied at: pasca.unhas.ac.id/jurnal/files/710d 3ccb784f720f572c99cbd59c1e7e.pdf

4 Dina Sunyowati, "Tata Kelola Kelautan Berdasarkan integrated coastal and ocean management untuk Pembangunan Kelautan Berkelanjutan", Jurnal PERSPEKTIF, Vol. XV No. 1, January 2010, p. 78.
}

pinning related to the application and process of Law of Society 5 .

As Banakar and Travers suggest, law is conceived as a social institution, just like religion, medicine, or education and can be learnt using the same method and technique. They add that abundant attention to following a specified method can even limit creativity and imagination in the research by requiring obligatorily a standard law research as well as legal institution. At this point, the absence of a method text can be considered as a good thing because it will help socio-legal research as an actual interdisciplinary study field, opened to diversity and theoretical innovation. ${ }^{6}$ Therefore, through social character, to achieve the objective of research, in-depth interview and observation were conducted on the areas where reclamation activity occurs, complemented with secondary data in the form of document study to find the factor causing disharmony in reclamation licensing in Sampang and Bangkalan Regencies.

The research took place in East Java with reclamation activities particularly Sampang and Bangkalan regencies. The hearing session was held as well to support the primary data. The document for secondary data was also analyzed.

\section{Discussion}

Coastal areas are natural resources that should be equally managed for national development sustainability. To present, the natural resources play significant roles for national economic growth. In this regards, the policy of coastal areas development must prioritize the controlling principle application through licensing system.

The scope of reclamation management in coastal areas through licensing system is governed in the Presidential Regulation Number 122 Year 2012 and the Law of Ministry Number 28 Year 2014 as the amended Law of Ministry

5 Bambang Sunggono, 2006, Pengantar Metode Penelitian Hukum, p. 3 in Murni and Sri Maharani MTVM., "Badan Penyelesaian Sengketa Konsumen sebagai Perwujudan Perlindungan Hak Konsumen", Arena Hukum, Vol 8 No 2, 2015, p. 206.

6 Reza banakar and Max Travers, 2005, Theory and Method in Socio-Legal Research, Onati: Hart Publishing Oxford and Portland Oregon, p. ix-x. 
Number 17 Year 2013. Government in the central level, district government, and every party who will do reclamation must entitle site permit and the implementation reclamation (See Article 15 Presidential Regulation Number 122 Year 2012).

To grant a site permit and reclamation license, the government, district government, and any party must submit proposal to Ministry, province/city governor, authorized to: first, The Ministry grants site permit and reclamation license to specific National Strategic Areas, reclamation activities across provinces, the coastal reclamation in fishery ports managed by the government. Second, the grant of site permit and reclamation license in specific National Strategic Areas and reclamation activities across provinces granted by the regent/mayor and governor consideration. Governor and the regent/ mayor grant the site permit and the reclamation license in the region which meet their authorities and reclamation activities in fishery ports that are managed by the district government (See Article 16 Presidential Regulation Number 122 Year 2012).

Coastal reclamation activities are mostly done to get new extended lands in strategic areas. The reclamation done in Sampang regency is massive, and most of coasts in Camplong are covered by new lands as a result of reclamation. Most of them were licensed by the head of the villages. The people submit the proposal of reclamation and are subsequently required to make a statement of willingness to return the land to the State when needed. ${ }^{7}$

The policy to the reclamation activities in Sampang regency remains a private sector so that the integration in its management does not occur. Each technical institution of district government related to reclamation such as The $\mathrm{Li}$ censing Office, Development Planning Agency in Sub-National Level, Revenue Offices, Marine and Fishery Offices carry out their authorities separately. The National Defense Office in this case the Land Registry Office of Sampang regency as the authority to issue the right of land

Based on the researchers' investigation during April-August 2017 in Sampang. never manages with the district government in issuing the land certificate as a result of reclamation for the reason of the complete administrative requirement and the absence of regional Acts organized. ${ }^{8}$ From 2015 to 2016, the district government of Sampang regency has proposed the evaluation of District Act Planning about reclamation, but the government of East Java province refuted it. ${ }^{9}$ Referring to the given regulation, when Ujung Piring coastal area devised to be reclaimed by Polairud Polres Bangkalan or other applicants, it is necessarily viewed whether the area belongs to central or local government.

Government Regulation Number 26 of 2008 on Rencana Tata Ruang Wilayah Nasional (RTRWN)/National Area Layout Plan) (thereafter called Goverment Regulation Number 26 Year 2008), as amended by Government Regulation Number 13 of 2017 on the amendment to Government Regulation Number 26 Year 2008 concerning RTRWN in appendix $X$ Number 33, states that Gresik - Bangkalan - Mojokerto - Surabaya - Sidoarjo - Lamongan (Gerbangkertosusila) urban areas (East Java Province) belong to National Strategic Area (See Goverment Regulation Number 26 Year 2008 jo Goverment Regulation Number 13 Year 2017 Appendix X). Therefore, reclamation activity conducted by urban (coastal) area of Bangkalan should get license from central government, in this case Kementerian Kelautan dan Perikanan (Maritime and Fishery Ministry) (thereafter called KKP) (Article 1 Number 22 of Maritime and Fishery Ministry Regulation Number 17 Year 2013).

The license issued by KKP for the implementation of coastal reclamation in Bangkalan Regency based on Article 5 of Maritime and Fishery Ministry Regulation Number 17 Year 2013 consisting of reclamation location license and coastal water reclamation implementation license in National Strategic Area is published after the Bangkalan Regent and East Java Governor's deliberation. The deliberation relates

Rina Yulianti. et. al., Op.Cit., p. 70.

Interview with the chairperson of Legislation in the Sampang Governmental Law Division, on August $4^{\text {th }}$, 2017. 
to the locations of reclamation and reclamation material source.

The deliberation related to reclamation location should be assessed as an attempt of synchronizing the Local Regulation on Bangkalan Local Area Spatial Layout Number 10 Year 2009. In addition, what needs to be constructed further is regulation of Coastal Area Zoning as the foundation of publishing Reclamation License. Moreover, the requirements of reclamation is governed in Permen Pekerjaan Umum (Public Work Minister's Regulation) Number 40/PRT/M/ 2007 on Coastal Reclamation Area Spatial Layout Plan Guideline. The guideline of reclamation specifies the presence of compulsory requirement of developing a Rencana Detail Tata Ruang (RDTR) (Spatial Layout Detail Plan) of a region. Spatial Layout Detail Plan of reclamation region can be developed when the following administrative requirements have been met: first, having RTRW already specified with Local Regulation; second, reclamation location that has been specified with Regent/Mayor's Decree; third, feasibility study has been conducted, and fourth, AMDAL study has been conducted on the area or region. Reclamation license the applicant, in this case Polairud (Polres Bangkalan) should have included site permit and implementation license given by KKP through Bangkalan Regent and East Java Governor's deliberation.

The Presidential Regulation Number 122 Year 2012 has regulated the license of reclamation. However, it is inadequate to solve the authority conflict in issuing the reclamation permission. The authority conflict also occurs in the Governor of the Special Region of Jakarta (DKI Jakarta) and Ministry of Maritime Affairs and Fisheries. Basuki Tjahaja Purnama (Ahok) as the governor of the Special Region of Jakarta confirms the reclamation activities in Jakarta Bay refer to Presidential Decision Number 52 Year 1995 on the reclamation in the North Coast of Jakarta. He argues that the given Presidential Regulation just altered the spatial planning only. The permission is still applicable. The licensing polemic vertically and horizontally has been the subject for debate and indicates disintegrated system in licensing the reclamation activities. Integrated planning and management of coastal area development are intended to coordinate and to direct a variety of activities of two or more sectors in planning development in relation to coastal area management. ${ }^{10}$

The approach of ICM enacted in the Law Number 27 Year 2007 reflected in setting the coastal management principles on Article 3 which stated that Coastal Area Management and small islands based on: sustainability, consistency, integration, legal certainty, partnership, equity, society participation, openness, decentralization, accountability, and justice. The explanation Article 3 Paragraph C the Law Number 27 Year 2007 on the integrated principles is to: first, integrate the policy and planning across government sectors horizontally and vertically between the government in the central level and regional government; and second, integrate land ecosystem and sea ecosystem based on the science and technology interference to help the process of decision making in the coastal area management and small islands.

Conceptually, integration is an important factor. Dahuri defines the integration from: intersectoral, governmental, spatial (space), Science and management, and International. Integrated planning aims to coordinate and direct any activities from two or more sectors in development planning related to coastal area and marine management. Integrated planning normally means to have programmed efforts for goal achievement that harmonize and maximize the interest in protecting the environment, people participation, and economic development.

The foundation of legislation should refer to juridical, sociological and philosophical foundations. Juridical foundation is vital because it is related to the obligations, firstly that there should be legislator's author; secondly that there should be a compatibility of law product form or type to the material governed; thirdly, the obligation to follow certain way, namely, the procedure of academic script pre-

\footnotetext{
Alex Fransisca, “Tingkat Pencemaran Perairan Ditinjau Dari Pemanfaatan Ruang di Wilayah Pesisir Kota Cilegon", Journal of Regional and City Planning, [S.l.], Vol. 22 No. 2, August 2011. p. 145-160.
} 
paring process, design submission, discussion, ratification and enactment; and fourthly obligation is not in contradiction with the higher-level legislation. ${ }^{11}$

The second foundation is sociological foundation in which legislation should answer and solve the problem occurring in the society. "A thing to remember is that the reality living within society as the sociological foundation should include the people's tendencies and expectation". Meanwhile, philosophical foundation refers to the spirit of legal ideal expected from the presence of a regulation. ${ }^{12}$

The integration basis in the Law Number 27 Year 2007 does not underlie the further explanation of coastal reclamation license regulation. Disharmony of licensing regulation occurs in authorities to issue the permit; the current investigation identifies the following problems: first, the district government ignores the district legislation of spatial plans. Consequently, the ignorance of reclamation activities in which the license is issued by unauthorized institutions occurs. Second, the district government did not arrange the regulation of coastal zoning plans, leading to sector egocentrism between offices in managing the coastal areas for reclamation activities. Third, the district government did not do harmonization to the Acts of districts related to spatial plans in district level and national level which results in misimplementation in granting the reclamation license. Fourth, there is no clear statement in normative concept related to Presidential Regulation Number 122 Year 2012 to terminate the existing regulations contributing to authority conflict in issuing the reclamation license.

The harmonization of law regulation should consider the presence of legislation hierarchy. Philipus M. Hadjon divides the type of law and ordinance into three main legal products: Constitution, Law, and Regulation. Through the classification, it can be seen clearly that in

11 Sukardi dan E. Prajwalita Widiati, "Pendelegasian Pengaturan oleh Undang-Undang kepada Peraturan yang Lebih Rendah dan Akibat Hukumnya", Yuridika, Vol. 27 No 2, May-August 2012, p. 145. its development, first, UUD is produced by MPR (House of Representative; second, Law is the product of legislation (DPR along with President); and third, Regulation is an executive product in the attempt of regulation. The classification will be automatically related to content material and shows hierarchy. Through formulating the type of law and ordinance into 3 (three) categories, without mentioning the hierarchy, the type automatically shows the hierarchy..$^{13}$ Integration of coastal reclamation regulation should consider the hierarchy to harmonize regulations, reclamation li-censing in both Sampang and Bangkalan Regencies has not met this criteria yet due to contradiction between local regulation and the higher reclamation regulation.

National Law Building Agency of Justice Department defines law harmonization as a scientific activity toward the process of harmonizing written law referring to philosophical, sociological, economic, and juridical values. The study on the draft legislation is intended to find out whether or not in many aspects it has reflected on synchrony and harmony with other legislation, non-written law living within society, convention and international agreement, bilateral or multilateral, ratified by Indonesia. ${ }^{14}$

Harmonization is defined as an attempt or process of realizing synchrony, harmony, compatibility, match, and balance among legal norms in legislation as the legal system in a unity of national legal system framework. Thus, the legal norm in legislation as a subsystem of national legal system framework is not inhibited with differences and contradiction, and there is no duplication or overlapping. ${ }^{15}$

The formulation of ideal measure in harmonizing the national legal system is an attempt of synchronizing, harmonizing, adjusting, balancing, and attempting consistency of legal

13 Titik Triwulan Tutik, “Analisis Kedudukan dan Status Hukum Ketetapan MPR RI Berdasarkan Undang-Undang Nomor 12 Tahun 2011 tentang Pembentukan Peraturan Perundang-Undangan", Jurnal Hukum Ius Quia lustum, Vol. 20 No. 1 January 2013, p. 1 - 20.

14 Kusnu Goesniadhie Slamet, "Harmonisasi Hukum dalam Perspektif Perundang-Undangan”, Jurnal Hukum lus Quia lustum, Vol.11 No. 27, September 2004, p. 82 - 96.

15 Ibid 
system elements of integrating a variety of legal systems. Thus it is organized in a harmonious order in the frame of national legal system. Thus, the attempt of harmonizing national system is a sine qua non condition for the assurance of law certainty, law orderliness, law enforcement, and law protection based on justice and truth. ${ }^{16}$

Disharmony occurring in Bangkalan and Sampang Regency over the reclamation licensing regulation should be responded immediately through developing licensing regulation by taking the integrated relationship pattern between central and local government into account. Therefore, the formulation of reclamation policy harmonization regulation model is conducted through developing: first, policy in the form of Local Strategic Living Environment Study regulation (KLHS); second, policy of Local Area Spatial Layout Plan (RTRW) regulation in harmony with National Area Spatial Layout Plan (RTRW) hierarchically; third, policy of Local Coastal Area Zoning Plan (RZWP) regulation.

The quality of Law tools cannot be determined by various number of legislation, however, to some extent; the regulation can accommodate and govern any legal problems for long term period. Therefore, the amendment to the existing regulation in a short term period can be avoided. Considering the dynamic conditions and legal problems appear after the legislation is designated and come into force, it is crucial to develop an integrated setting plan, either across various types of the same legislation, or with other interrelated legislation in accordance with the State's vision and mission.

\section{Conclusion}

The factor causing disharmony of reclamation licensing regulation in Sampang Regency is that the Local Government has not developed the regulation of coastal area zoning plan; it leads to sectoral ego between services in managing coastal area for reclamation. Meanwhile, Bangkalan Regency Government has not syn- chronized the Local Regulation on its Area Spatial Layout Plan (RTRW) and National Area Spatial Layout Plan; it results in misapplication if issuing the reclamation licensing.

\section{Suggestion}

Harmonization becomes an important part of constructing an integrative law in order to realize similar patterns of central and local authorities in introducing the policy to control of coastal spatial usage. The disharmony in issuing coastal reclamation license leads to the vertical or horizontal conflicts among authorities. Its harmonization must consider the hierarchical principles of the Law to suit any conflicting, awkward, and disproportional cases for integrated system.

\section{References}

Banakar, Reza and Max Travers. 2005. Theory and Method in Socio-Legal Research. Onati: Hart Publishing oxford and Portland Oregon;

Fransisca, Alex. "Tingkat Pencemaran Perairan Ditinjau Dari Pemanfaatan Ruang di Wilayah Pesisir Kota Cilegon". Journal of Regional and City Planning. Vol. 22 No. 2. August 2011. Pp. 145-160;

Murni and Sri Maharani MTVM. "Badan Penyelesaian Sengketa Konsumen sebagai Perwujudan Perlindungan Hak Konsumen". Arena Hukum. Vol 8. No 2 2015. Pp. 203-216. DOI: 10.21776/ub.arenahukum.2015.0080 2.4;

Slamet, Kusnu Goesniadhie. "Harmonisasi Hukum dalam Perspektif Perundang-Undangan”. Jurnal Hukum lus Quia lustum. Vol. 11 No. 27. September 2004. Pp. 82 - 96;

Suhayati. "Aspek Hukum Kebijakan Pemanfatan Tanah Hasil Reklamasi Pantai Losari di Kota Makassar". Jurnal Pasca FH Universitas Hasanuddin Makasar. Retrivied at: pasca.unhas.ac.id/jurnal/files/710d3ccb7 84f720f572c99cbd59c1e7e.pdf;

Sukardi and E. Prajwalita Widiati. "Pendelegasian Pengaturan oleh Undang-Undang kepada Peraturan yang Lebih Rendah dan Akibat Hukumnya". Yuridika. Vol. 27 No 2. May-August 2012. Pp. 141-156. DOI: 10. 20473/ydk.v27i2.293 
Sunyowati, Dina. "Tata Kelola Kelautan Berdasarkan integrated coastal and ocean management untuk Pembangunan Kelautan Berkelanjutan". Jurnal Perspektif. Vol. XV No. 1. January 2010. Pp. 76-97;

Titik Triwulan Tutik. "Analisis Kedudukan dan Status Hukum Ketetapan MPR RI Berdasarkan Undang-Undang Nomor 12 Tahun 2011 tentang Pembentukan Peraturan Perun-
dang-Undangan". Jurnal Hukum lus Quia lustum. Vol. 20 No. 1. January 2013. Pp. 1-20. DOI: 10.20885/iustum.vol20.iss1. art1

Yulianti, Rina. et. al. "Urgensi Pengaturan Reklamasi Pantai di Wilayah Pesisir Selatan Madura". Yustisia Vol. 4 No. 1. JanuaryApril 2015. Pp. 103-121. DOI: 10.20961/ yustisia.v4i1.8626. 